\title{
Feminist and Ecofeminist Christology ${ }^{\mathrm{i}}$
}

\author{
Ioanna Sahinidou ${ }^{1}$ \\ ${ }^{1}$ Wales University Trinity Saint David, Greece \\ Correspondence: Ioanna Sahinidou, 16 Lazeon str, 11741 Athens, Greece.
}

Received: January 24, 2018

doi:10.11114/ijsss.v6i4.3055

\author{
Accepted: February 21,2018 Available online: February 23, 2018 \\ URL: https://doi.org/10.11114/ijsss.v6i4.3055
}

\begin{abstract}
The Incarnation of Christ, known by the eastern fathers as Christological perichoresis as a theological idea becomes experienced ecological reality, if we realize its kenotic, Christological, relating cosmic dimensions. It shows how we can bring together different entities, such as God and nature, look at them in unity, as the one person of Christ, and acknowledge the perichoresis between divine and human and nature. Christ lived as one person: both God-Creator and creature. If ecofeminist theologies need a place in the Christian church, they must seek a Christological salvific foundation. Our encounter with God in Christ is a transformation and a renewal of ourselves so as to discern the will of God and follow it; a kenosis of our egocentric self so that Christ to be reborn in us. Paul sees the encounter with God as a rebirth, not as intellectually gained knowledge.
\end{abstract}

Keywords: feminism, ecofemism, christology, christological perichoresis, ecology

\section{Feminist Christology}

'Can a male saviour save women?' (Ruether, 1993) ${ }^{\mathrm{ii}}$ Classical Christology brings together two ideas: that of a messianic king of a time of redemption and that of divine wisdom that grounds the cosmos uniting the human and the divine. The patriarchalization of those issues happens by repression in both Judaism and Christianity of the female symbol. Christianity changed, within the messianic renewal movement of first century Judaism into the new religion of the Roman Empire. Women could not represent Christ, the leader of the existing social hierarchy who appeared as male God whom only a man can represent. In Aristotelian biology (Aristotle, 1993, 1994)) ${ }^{\mathrm{iii}}$ procreative power was known as only male-capacity; the female was the 'passive recipient-incubator' of the male seed that had generative power. (Ruether, 1993) $)^{\text {iv }}$ In medieval scholasticism this Christology is argued both on symbolic and biological contexts. The male, thought to be the generic sex of the human species, represents the fullness of human nature; woman is defective both physically and morally. The incarnation of Logos (Word) into a male was thought to be an ontological necessity. Only the male can represent Christ, and his own representatives must be males. A Christology that identifies the maleness of the historical Christ and of the divine Logos, with normative humanity excludes women to represent Christ, and sees them as second-class citizens in both creation and redemption. Yet Christianity offers alternative Christologies. For androgynous Christologies (Ruether, 1993) ${ }^{v}$ the split of maleness-femaleness ends in redeemed humanity. Their root lies in the belief that Christ redeems the entire human nature, male and female, an idea grounded on Gal. 1.28. (Ruether, 1993) ${ }^{\mathrm{vi}}$ Behind the androgynous Christologies lies often the idea of an original androgyne that existed, according to which Adam contained both male and female. The splitting of the female from the male side of Adam results in the fall of humanity and the advent of sex and sin. Christ, the new androgynous Adam, helps the redeemed to regain their humanity. In Christ, the male gains a model of androgyny of a person both commanding and nurturing. While the female relates to a mothering person, she does not gain a comparable androgyny. The concept of perichoresis emerges at the time between Aristotle and Aquinas. Despite the patriarchal, military structure of social life, a part of mainstream theological anthropology recognized the androgynous anthropology and Christology. According to Cyril of Alexandria, in an anthropocentric but not androcentric text the human being man or woman, yet not just man is an icon of godly ruling on earth: ' $\theta \varepsilon \circ \pi \rho \varepsilon \pi \circ \tilde{v} \varsigma$ غ̇ं things hold together (Colossians 1:15-17) who is everything for all: father, brother, bridegroom, dwelling, clothing, root, friend, head, sister, and mother.

Christ was born of a virgin according to the scriptures, as no human being has ever been born. The mother of Christ did not have sexual intercourse with any man. Christ incarnated received a human nature from his mother, but he did not receive a genetic code from a human father. Then humanly speaking Christ could be seen as not a complete human being, 
since he did not take anything from a human father. In human beings, men possess the chromosome that determines the gender of the embryo. Yet such a 'logical' analysis of Christ's natures leads nowhere. The 'how' he became a human/ divine person in his compound unique hypostasis as different from his Father and the Spirit as well as from his mother and from us, is a mystery. ( $\Delta \alpha \mu \alpha \sigma \kappa \eta v o v$, 1989) $)^{\text {viii }}$ To discuss 'how' the human and divine natures became one hypostasis transcends human understanding. The incarnation of Christ, the creation of the world, and of life itself and the sustenance of the world and of life could be known only as a mystery.

Jesus proclaims a reversal of the religious status, aiming at a reality where hierarchy and dominance are overcome as principles of social relations. The last shall be first and the first last (Matthew 19.30). Jesus saw the leaders of the reli gious establishment as blind guides and hypocrites (Matthew 23.15-6, 23.1-7). Yet relation to God liberates us from hierarchical relations, making us brothers and sisters (Matthew 23.8). The leaders must become servants of all (Matthew 26-8). The gospels do not use a dualism of masculine-feminine, but protest against the social realities where maleness and femaleness along with class, ethnicity and religious office define social status. Jesus as liberator does not reside in his maleness; he embodies the new humanity of service. Women find liberating stories about Jesus' reversals of patriarchal families and of women involved in his ministry. There is transformative truth in Jesus' openness to women. His inclusion of women disciples, his friendship with Mary Magdalene, women in the parables, his breaking of taboos in speaking with the Samaritan (John 4.1-42) and the Syro-Phoenician women (Mark 7.24-30), women as first witnesses of the resurrection (Matthew 28.8-9) are bedrock for feminist Christology. (Carr, 1996) ${ }^{\mathrm{ix}}$ The inclusiveness of feminist Christology is based on women's appearance among the marginalised: the poor, the sick, the prostitutes. God will make their cause God's concern, a promise to be seen as proclamation of the poor's rights and God's justice. (Fiorenza, 2000) ${ }^{\mathrm{x}}$ Jesus does not propose a structural change; he subverts the oppressive structures by envisioning both different future and human relationships. By setting free those in bondage to evil powers, Christ subverts patriarchal structures. His mother, a woman, represents the hope of both poor men and women: '(God) filled the hungry with good things but sent the rich away empty' (Luke 1:51-53). Christ came to earth as a man. Putting this into its biblical context, rarely the word àví $\rho$-man is used. "Av $\theta \rho \omega \pi$ o -human being is used, where in Greek both sexes are included. In Christological perichoresis, the divinity is united through the Father and the Spirit with humanity not with mankind. John of Damascus speaks of Christ's two natures as divine and human, never divine and male. Christ is connected with the Father and the Spirit and in respect of His humanity with His mother and us, not with mankind. $(\Delta \alpha \mu \alpha \sigma \kappa \eta v o v ́)^{\mathrm{xi}}$ Christ became 'flesh'; both men and women are 'flesh'.

A biblical verse that was used to undervalue women is the following: 'I want you to realize that the head of every man is Christ, and the head of the woman is man, and the head of Christ is God (1 Cor. 11.3) Yet if we consider Christ and God the Father as peers in the phrase: 'the head of Christ is God,' we also confess that man and woman are known as peers in the phrase: 'the head of the woman is man.' Paul safeguards the parity of men and women in Christ. If the parity of men

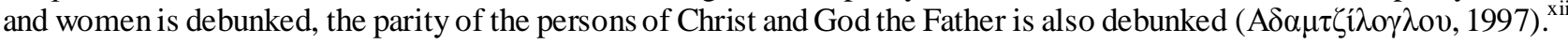

The focus on the damage to women by men legitimated sexual and physical abuse and the rhetoric of cruciform redemption shows the perilous path of women. Coakley describes a danger to Christian feminism is a failure to face issues of fragility, suffering, or 'self-emptying' (except victimology) that blocks a feminist re-conceptualization of the power of the cross and resurrection. Only by reconstructing the paradox of 'losing one's life to save it' can feminists envision the moving of Christ beyond gender stereotypes, beyond kenosis as a dogma about Christ and accept the call of Philippians 2 to enter into Christ's life. If abusive human power is in our grasp, how can we reach the healing resources of a non-abusive divine power, if not by an opening of the self to Christic transformation? Space making, as yielding to divine power, marks a willed engagement with the cross and resurrection, a deep rooting into Christ's body. By 'making space for Christ,' one practices the enabling presence of a God who does not force. The human vulnerability is not to ask for unnecessary suffering or self-abnegation. 'Self-emptying' is not a negation of self, but rather the place of the self's transformation in God.

We must make distinctions in feminist theology between special vulnerability and invitation to abuse; self-effacement and self-destruction; wilful creative suffering and pain for pain's sake; a cross-theology and women's abuse in the name of the cross. While kenosis may for women be misconstrued as 'appropriate' sexual submission, we cannot rest while such views of gender still exist. Feminists seek personal empowerment, prophetic resistance, courage against oppression and the destruction of idolatry. 'Making space' is painful as the new self struggles to birth. A transformation ignored by post-modern Christian feminism can keep us as Christian feminists. (Coakley, 2002). ${ }^{\text {xiii }}$ The claim of feminist theology that a human community existing in mutuality rather than hierarchy is icon of God's relational life could be realized in the economy of salvation and in human community proclaimed by Jesus, as attributes of God's reign. Feminist analyses of Christ's life are rooted in the divine-human relations, according to LaCugna (LaCugna, 1996). ${ }^{\text {xiv }}$ The biblical verses: John 17:21-23, could function as a witness to such an understanding. 


\section{Ecofeminist Christology}

To seek biblical readings from an ecofeminist perspective and to search for earth-friendly traditions revealing new insights could challenge the anthropocentric voices of the biblical text (Hallman, 1995). ${ }^{\mathrm{xV}}$ Some views de veloped to a political or social criticism deconstruct the traditional patriarchal power-relation network. The politicians and scientists who framed for the 1950-51 UNESCO documents on racial differences were poised on the boundary between fascism and colonization on the one side, and multi-nationalism, decolonization and Cold War on the other. Before World War II, versions of Darwinist 'natural selection' were implicated in validating racist politics. For the constitution of UNESCO, the last war was based on the idea of inequality among human races. The 1950 document was a new synthesis: natural selection and population biology were seen as complexity; bio-efficiency and adaptive flexibility were committed to the human place in nature, stressing cooperation, dignity, and the control of aggression-war and progress (Primavesi, 2000). ${ }^{\mathrm{xvi}}$

Seeking a covenant of integration with nature, we find inspirational sources in the feminine. By instinct women live out the complexity and interconnection of the real, as connected to what is most complex in the cosmos, namely life, by being the immediate generators of life. They carry the mystery of human life in their womb and comfort it throughout its existence. Women are related to life more by care than by labour; and the logic of the complex comes into play (Boff, 1997) ${ }^{\text {xii }}$ Feminist criticism supports a radical re-examination of anthropology (Moore, 1999). ${ }^{\text {xviii }}$ Ecofeminism stands critically against rationalism, authoritarianism, the will to power, historic expressions of patriarchalism constructively, through relating to nature a view of kinship and a cosmic sacredness (Merchant, 1980). ${ }^{\text {ix }}$

\section{Platonic Dual isms Infl uence the Christian Cosmic Vision}

Plato and Aristotle used a hierarchy uniting the female, the alien, and the animal as 'natural' inferiors in a 'chain'

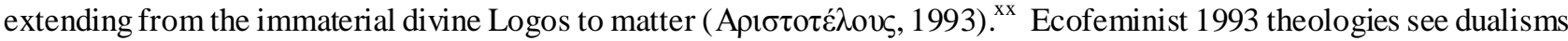
within the human person as soul-body, between human beings, and between humanity and nature. If human society needs a home in nature, then the human soul needs a home in the existence of each human being. ${ }^{\mathrm{xxi}}$ Feminist theology reconstructs theology in the (A context where women live, considering gender as a tool to emphasize the deficiency of theories that use biology to explain the inequality between men and women. When speaking of gender, we know our being is more than mere biology, but also inclusive of history, religion. My ecofeminist theological searching connects to a Christological approach.

According to Gregory of Nyssa, humans could not appear before the rest of creation. When their dominion was prepared, God manifests humans as beholders and lords of the world and its wonders. The words: ruler, king, lord legitimize today a dominion theology. Gregory's text in the Platonic hierarchical but organic worldview prevailed in the church fathers' era, where humans enjoy the cosmos and trace the power of the Maker to not see dominion as utilitarianism. Gregory of Nyssa accepts two creations for humanity. In the first creation of Adam, all humanity is included ${ }^{\mathrm{xxii}}$ because 'God created the human being in the image of God.' The image extends to the entire race since mind is implanted alike in all. The divine nature finds its image in that which was made according to it: the human being, created at the first creation and that which shall be after the consummation of all. Both bear the divine image.

We can trace Gnostic influences in Gregory's of Nyssa text when he realizes Adam as initially containing both male and female. According to Gregory, two natures-the incorporeal divine and the irrational life of brutes-are separated from each other as extremes. In the human compound nature, we may behold a part of each of the natures: of the divine, the rational element that does not admit the distinction of male and female and of the irrational bodily structure: divided into male and female. Platonic ideas appear both when Gregory sees mind-voṽ as the sign that makes humans in the image of God and when God is thought as rational. Gregory also sees the brutes as irrational, and that humans include both rational and irrational elements. In the first creation, the male and female are separated; in redeemed humanity, both male and female are included.

Patristic theology was grounded on terms like essence, hypostasis, and energy. What those ideas have to do today with DNA, the neurobiological brain functioning, and of cultural diversities of our times? If the way the cosmos exists cannot be known by reason, God's unfathomable for our limited, human knowing ways, can open new ways for us. ${ }^{\text {xiii }}$ Theologians must be selective in what they reclaim from earlier theologians in order to offer theological tools and express a theological cosmic vision. Christian cosmology inherited problems from Platonic ideas as a geocentric, anthropocentric, hierarchical worldview. According to Aristotle, the earth occupies the centre of the $\operatorname{cosmos}{ }^{\text {xxiv }}{ }^{x x v}$ In the church fathers' era, the cosmos was conceived of with the earth at the centre surrounded by the planets that were moving around the earth; then the sphere of the fixed stars; beyond them, the eternal space of God's dwelling. The Ptolemaic geocentric system before Copernicus, dominated Byzantine astronomical theory, the Islamic world, and medieval Europe. ${ }^{\mathrm{xxvi}}$ According to Cosmas Indicopleustes, the earth was flat. ${ }^{\text {xxvii }}$ To place humans at the centre of such a cosmos seems natural. Later science expanded our knowing of the cosmic history; a sense of the whole was lost, as was the interrelationship of everything with all. Theological and scientific truths were both disconnected from the idea of communion, and seen as a 
subject-object framework for a methodology of analytical research. Einstein re-oriented the scientific search for truth: now in the natural sciences, existence is known as relational.

According to Val Plumwood the set of mutually reinforcing dualisms that permeate western culture now forms a fault-line, running through the conceptual system. The human/nature contrast can be known as part of the interrelated set that should be seen as forming an interlocking structure. Dualistic key elements in western thought are the following pairs:

\begin{tabular}{|c|c|}
\hline Culture & / nature \\
\hline Reason & / nature \\
\hline Male & / female \\
\hline Mind & / body (nature) \\
\hline Master & / slave \\
\hline Reason & / matter (physicality) \\
\hline \multicolumn{2}{|c|}{ Rationality / animality } \\
\hline Reason & /emotion \\
\hline \multicolumn{2}{|c|}{ Mind, spirit / nature } \\
\hline Freedom & / necessity (nature) \\
\hline Universal & / particular \\
\hline Human & / nature (non-human) \\
\hline Civilized & / primitive (nature) \\
\hline Production & / reproduction \\
\hline Public & / private \\
\hline Subject & / object \\
\hline Self & / other \\
\hline
\end{tabular}

The list is not complete; we can see any distinction as dualism. Dualisms as reason-nature are associated with post enlightenment consciousness. Even the ancient ones do not fade away when their original context changes, but they are usually preserved in our conceptual framework as layers of sediment deposited by past situations. Old situations stored as dualisms break the path for new ones. ${ }^{\text {xxviii }}$ The Earth Bible Team copies the dualistic pairs from Plumwood, underlying that they are so much part of our view of reality in the west that we tend to assume that they describe reality. ${ }^{\text {xxix }}$

\section{Christolocal Perichoresis ${ }^{\mathrm{xx}}$ Builds up an Ecofeminist Worldview}

In my thesis, I defend a Christological, perichoretic non-anthropocentric worldview that unites the temporal with the eternal, the divine with the cosmic in Christ in contrast to an ecofeminist Christological view that lost its soteriological content. Among feminist theologians, LaCugna argued that in the economy of redemption, perichoresis is located not in God's inner trinitarian life as Moltmann claims but in the mystery of the communion of both divine and human pers ons. One perichoresis includes God and humanity. In my view, Christological perichoresis is the kind of perichoresis to apply to ecofeminism. ${ }^{\text {xxi }}$ I extend LaCugna's feminist Christological perichoretic view, making new connections of tradition and contemporary resources as ecology and cosmology: the one perichoresis that includes God and humanity ${ }^{\text {xxxii }}$ according to LaCugna can include the entire creation in Christ.

The relations between the divine and fleshy natures of Christ permeate ineffably through not just human flesh. This becomes a key idea for theological anthropology undercutting ideas of human existence apart from the rest of creation. ${ }^{\text {xxxiii }}$ Realizing the Word as creator and re-creator of creation from non-being into being, a Christian scientist can recognize the task that can free nature from exploitation under modern technocratic cultures. ${ }^{\text {xxiv }}$ The vision of the eastern fathers may help us discern and retrieve the idea of Christological perichoresis springing panentheistically from trinitarian perichoresis and the sense of the whole lost in the mechanistic era. The relationship between the created and the uncreated is based on the 'union without confusion,' between divine and human nature in the one Christ incarnate. ${ }^{\mathrm{xxx}}$ In my view, the Christological reading of perichoresis can be an original starting point in perceiving both the economy of incarnation and resurrection that places perichoresis in the mystery of the communion between the trinity and the cosmos, challenging all dualisms. ${ }^{\text {xxvi }}$ 'Creation will be liberated from its bondage to decay' (Romans: 8. 21).

Christological perichoresis supports the idea that the whole creation will be included in God's recreated cosmos responding to the redeeming power of Christ (John 1.14) who became flesh, entering the web of life as a creature to save 
it from death. It also supports my idea that trinitarian relationships go further than the cosmological ecofeminist mode of relatedness, bearing a Christological message for wilful openness towards the 'other.'

This theological idea allows me to respond to ecofeminism from a Christian view realizing Christ's cosmic role in the salvation of the entire cosmos. I made my case for a Christological perichoresis as an evolutionary step further in the direction of ecofeminist theology. The Christological reading of perichoresis can be an original contribution respecting my ecofeminist, Christian view. ${ }^{\text {xxvii }}$ A main contribution of ecofeminist theologies is that they stretch the limits of Christology and sal vation toward ecological responsibility and a vision of cosmic salvation. Since Augustine in the west, theology emphasizes human uniqueness focusing the doctrine of redemption on the salvation of the human soul. Howe ver, the anthropocentric conception of salvation led to the exclusion of non-human creation from the vision of redemption realizing only humans as the object of divine cosmic concern. ${ }^{\text {xxxviii }}$

\section{Epilogue}

Ecofeminist theologies challenge the use of Christology as a witness for patriarchal structures in both church and society that keep the domination of one sex over the other and permit exploitation of the ecosystems as well. ${ }^{\text {xxxix }}$ Christian trinitarianism reveals for Christians and affirms for modern science, the sacred cosmic nature. ${ }^{\mathrm{xl}}$ Christ lived as one person: both God-Creator and creature. If ecofeminist theologies need a place in the Christian church, they must seek a Christological salvific foundation. ${ }^{x l i}$ Our encounter with God in Christ is a transformation and a renewal of ourselves so as to discern the will of God and follow it; a kenosis of our egocentric self so that Christ to be reborn in us. Paul sees the encounter with God as a rebirth, not as intellectually gained knowledge (John 3.7-8).

Christological perichoresis springs from the divinity permeating ineffably through flesh to glorify it. This understanding could have crucial implications for theological anthropology, undercutting ideas of human life apart from creation. Perichoresis as a theological idea becomes experienced ecological reality, if we realize its kenotic Christological, relating, cosmic dimensions. I reclaim the patristic Christological use of perichoresis to show how we could bring together different entities, such as God and nature, look at them in unity, as the one person of Christ, and acknowledge the perichoresis between divine and human, divine and nature. ${ }^{\text {xli }}$

\section{References}

Adams, C. J. (ed.), Ecofeminism and the Sacred New York: Continuum, 1993), introduction.

Aristotle, Generation of Animals 729-75, Politics, 1254.

Blackburn, S. (1994). 'Ptolemaic system' in Oxford Dictionary of Philosophy. Oxford: Oxford University Press.

Boff, L. (1997). Cry of the Earth, Cry of the Poor. New York: Orbis Books.

Carr, A. E. (1996). Transforming Grace -Christian Tradition and Women's Experience. New York: Continuum.

Clayton, P., \& Peacocke, A. (ed) (2004). In whom we Live and Move and Have Our Being. Grand Rapids, Michigan/Cambridge, U.K: William B. Eerdmans Publishing Company.

Coakley, S. K., \& Subversion', in Coakley S. (2002). Powers and Submissions, Spirituality, Philosophy and Gender. Oxford: Blackwell Publishers. https://doi.org/10.1002/9780470693407

Cyril of Alexandria, Genesis Glaphyra, PG 69.20.

Cyril of Alexandria. 'Becoming Temples of God', Commentary to the Gospel of John PG. 70.

Fiorenza, E. S. (2000). In Memory of Her: A Feminist Theological Reconstruction of Christian Origins. New York: Crossroad.

Gregory of Nyssa. The Making of Man. PG 44.

Grey, M. (2003). Sacred Longings: Ecofeminist Theology and Globalization. London: SCM Press.

Habel, N. C. (ed.) (2000) Readings from the Perspective of Earth. Sheffield: Sheffield Academic Press.

Hallman D. G. (1990). 'Beyond North/South Dialogue', in Hallman D G. (ed.) (1995). Ecotheology Voices from South and North. New York: WCC Publications.

Indicopleustes C. ${ }^{\text {th }}$ century traveller, pre-Christian geographer, Christian Topography, PG 88.23-90, Book 2.

LaCugna, C. M. (1993). Godfor Us: The Trinity \& Christian Life. New York: HarperSanFrancisco.

McFague, S. (1930). The Body of God. Minneapolis: Fortress Press.

Merchant, C. (1980). The Death of Nature Women, Ecology and the Scientific Revolution. New York: HarperSanFrancisco. 
Moltmann, J. (1985). The Gifford Lectures 1984-5, God in Creation: An Ecological Doctrine of Creatio. London: SCM Press.

Moore, H. L. (ed.) (1999). Anthropological Theory Today. London: Polith Press.

Primavesi, A. (2000). Sacred Gaia. London, New York: Routledge. https://doi.org/10.4324/9780203451786

Ruether, R. R. (1993). Sexism and God-Talk. Boston: Beacon.

Ruether, R. R. (1999). Gaia and God, an Ecofeminist Theology for Earth Healing. New York: HarperSanFrancisco.

Sahinidou, I. (2014). Hope for the Suffering Ecosystems of our Planet? The Contextualization of Christological Perichoresis for the Contemporary Ecocrisis. Frankfurt: Peter Lang.

Sahinidou, I. (2017). 'Ecofeminist Theologies Challenge Domination' in Open Journal of Philosophy, Hubei Province, China: Scientific Research.

Sherrard, P. (1998). Christianity Lineaments of a Sacred Tradition. Brookline, Massachusetts: Holy Cross Orthodox Press.

Vischer, L. (ed.) (2004) Listening to Creation Groaning. Geneva: John Knox Series.

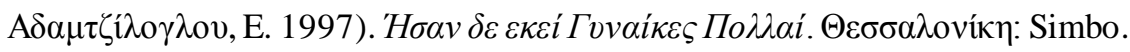

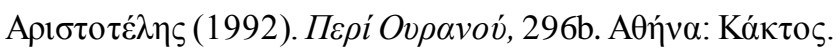

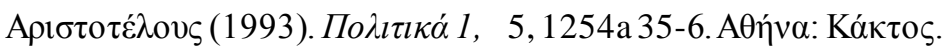

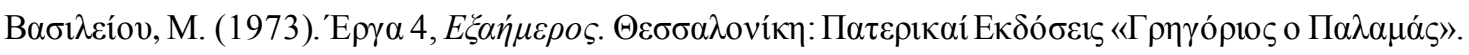

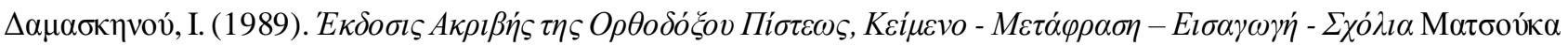

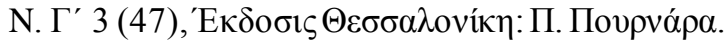

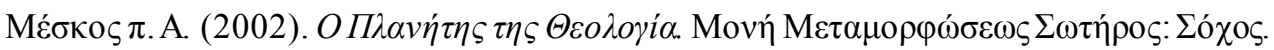

\section{Endnotes}

${ }^{\mathrm{i}}$ This article is part (reworked) of my published academic doctoral thesis: Sahinidou I. (2014). What Hope for the Suffering Ecosystems of our Planet? The Contextualization of Christological Perichoresis for the Contemporary Ecocrisis. Frankfurt: Peter Lang.

ii Ruether R. R. (1993). Sexism and God-Talk. Boston: Beacon. pp. 116-158.

iii Aristotle, Generation of Animals 729-75, Politics, 1254.

iv Ruether R. R. (1999). Gaia and God, an Ecofeminist Theology for Earth Healing. New York: HarperSanFrancisco. p. 184.

v Ruether uses the term 'androgynous christologies', where Christ as the representative of the new humanity unifies both male and female, Ruether R. R. Sexism and God-Talk, p.127

${ }^{\mathrm{vi}}$ Ruether, Sexism and God-Talk, pp. 116-26.

vii Cyril of Alexandria, Genesis Glaphyra, PG 69.20.

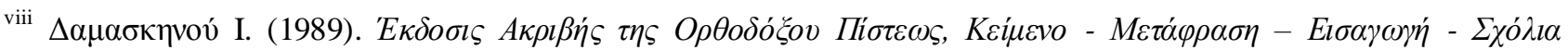

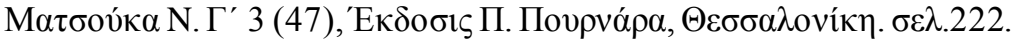

ix Carr A. E. (1996). Transforming Grace-Christian Tradition and Women's Experience. New York: Continuum. pp. $168-9$.

${ }^{x}$ Fiorenza E. S. (2000). In Memory of Her: A Feminist Theological Reconstruction of Christian Origins. New York: Crossroad. pp.122-5, 142.

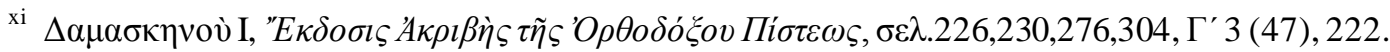

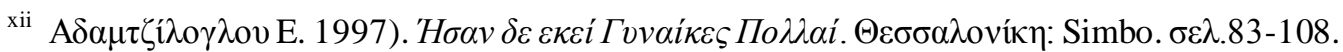

xiii Coakley S. 'Kenosis and Subversion', in Coakley S. (2002). Powers and Submissions, Spirituality, Philosophy and Gender. Oxford: Blackwell Publishers. pp.3-39.

xiv LaCugna C. M. (1993). Godfor Us: The Trinity \& Christian Life. New York: HarperSanFrancisco. pp.270-4. 
${ }^{x v}$ Hallman D. G. (199\%). 'Beyond North/South Dialogue', in Hallman D G. (ed.) (1995). Ecotheology Voices from South and North. New York: WCC Publications. pp.5,6.

${ }^{x v i}$ Primavesi A. (2000). Sacred Gaia. London, New York: Routledge. p.118.

xvii Boff L. (1997). Cry of the Earth, Cry of the Poor. New York: Orbis Books. pp. 26-7.

xviii Voluntaristic interpretations of gender work on the assumption that if sex is made up then it can be unmade. They reduce sexual difference to a construct of historically variable discursive practices, and reject the idea that there is anything constant about sexual difference. This rejection is an absolute one because the terms of the sex/gender debate resolve around the question of nature versus culture, essentialism versus construction, substance versus signification.

The main intellectual issue is how to reconcile theories that prefer unconscious desire to wilful choice, the unchanging structures of linguistic difference to destructive playfulness, the register of the symbolic to that of the social? The boundary between sex and gender may be unstable but that does not mean that they can be collapsed into each other. However, we should not confuse the instability of sexual signifiers with the imminent disappearance of women and men themselves, as we know them physically, symbolically and socially. We need to manage the sex/gender debate as we live our life that is as a complex relation between a radical materialism and a radical social constructionism. We do use our embodied selves as a point of reference even in the most abstract theoretical discussions. Henrietta Moore H. L. 'Whatever Happened to Women and Men? 'Gender and other Crises in Anthropology' in Moore H. LO. (ed.) (1999). Anthropological Theory Today. London: Polith Press. pp. 167-9.

xix Merchant C. (1980). The Death of Nature Women, Ecology and the Scientific Revolution. New York: HarperSanFrancisco.

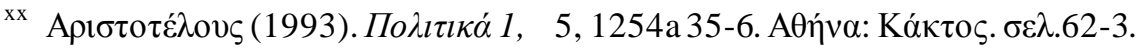

${ }^{x x i}$ Moltmann J. (1985). The Gifford Lectures 1984-5, God in Creation: An Ecological Doctrine of Creatio. London: SCM Press. pp.47-9.

xxii Gregory of Nyssa. The Making of Man. PG 44. 132-3,15.

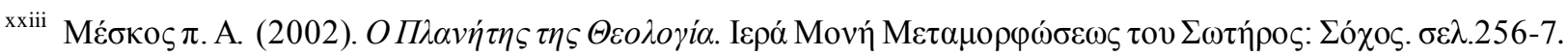

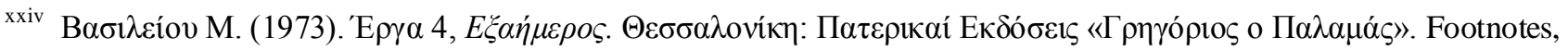
18 -20 by the translators. pp.54-7.

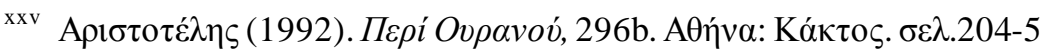

xxvi Blackburn S. (1994). 'Ptolemaic system' in Oxford Dictionary of Philosophy. Oxford: Oxford University Press. p.310.

xxvii Indicopleustes C. $6^{\text {th }}$ century traveller, pre-Christian geographer, Christian Topography, G 88.23-90, Book 2.

xxviii A further step towards the kind of rapprochement between science and theology may perhaps be found in quantum mechanics, where it is shown that the observer is involved in his measurement in an essential way. Subject and object are now related, thus bridging the gap between the two. The philosophical interpretation of quantum mechanics is still a matter of some dispute.

xxix The Earth Bible Team, 'Guiding Ecojustice Principles', in Habel N. C. (ed.) (2000) Readings from the Perspective of Earth. Sheffield: Sheffield Academic Press.

xxx The Easten Church Fathers quote the word from Anaxagoras where it means 'rotation' 'revolution'. The noun $\pi \varepsilon \rho \iota \chi \omega ́ p \eta \sigma \varsigma s$ names the dynamic process of making room for another around oneself, or to extend one's self round about. Theologically the term developed over the first seven centuries of the Church-history. When used by the Eastern Church Fathers, the concept of perichoresis offered a way of attempting to express the mutual indwelling or

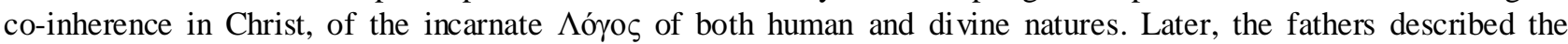
personal triune relationship of Father, Son and Spirit as perichoresis. The concept expressed how the unity and distinction are combined in the persons of the trinity, in the natures of Christ, as well as in creation as reunited with God.

xxxi Adams C. J. (ed.), Ecofeminism and the Sacred (New York: Continuum, 1993), introduction', pp.2-4.

xxxii Mowry, LaCugna Godfor Us, pp.270-74.

xxxiii McFague S. (1930). The Body of God. Minneapolis: Fortress Press. pp.105-6.

xxxiv 'The Cosmic Vision of Saint Maximos the Confessor', Clayton and Peacocke (eds), In whom we Live and Move and Have Our Being Louth, pp.194-6. 
xxxv Bishop Kallistos (Ware) of Giokleia, 'Foreword', Sherrard, Christianity Lineaments of a Sacred Tradition, p.xix.

${ }^{x x x v i}$ LaCugna, God for Us The Trinity \& Christian Life, pp.270-4.

xxxvii Grey, Mary, Sacred Longings: Ecofeminist Theology and Globalization (London: SCM Press, 2003), pp.72-74.

xxxviii Northcott M. 'Ecological Crisis and Environmental Ethics' in Vischer L. (ed.) (2004) Listening to Creation Groaning. Geneva: John Knox Series. p.212.

xxxix Grey, 'Ecofeminism and Christian Theology', p. 152.

${ }^{x 1}$ Alexei V. Nesteruk, 'The Universe as Hypostatic Inherence in the Logos of God', Philip Clayton and Arthur Peacocke (ed.), In whom we Live and Move and Have Our Being, p. 183.

xli Cyril of Alexandria, 'Becoming Temples of God', in Commentary to the Gospel of John PG. 70.

xlii Sahinidou I. (2017). 'Ecofeminist Theologies Challenge Domination' in Open Journal of Philosophy, Hubei Province, China: Scientific Research. 249-259.

\section{Copyrights}

Copyright for this article is retained by the author(s), with first publication rights granted to the journal.

This is an open-access article distributed under the terms and conditions of the Creative Commons Attribution license which permits unrestricted use, distribution, and reproduction in any medium, provided the original work is properly cited. 